University of California, Hastings College of the Law

UC Hastings Scholarship Repository

Faculty Scholarship

2021

\title{
COVID-19 Antibody Testing as a Precondition for Employment: Ethical and Legal Considerations
}

\author{
Sara Gerke \\ Gali Katznelson \\ Dorit R. Reiss \\ UC Hastings College of the Law, reissd@uchastings.edu \\ Carmel Shachar
}

Follow this and additional works at: https://repository.uchastings.edu/faculty_scholarship

\section{Recommended Citation}

Sara Gerke, Gali Katznelson, Dorit R. Reiss, and Carmel Shachar, COVID-19 Antibody Testing as a Precondition for Employment: Ethical and Legal Considerations, 49 J.L. Med. \& Ethics 293 (2021). Available at: https://repository.uchastings.edu/faculty_scholarship/1830

This Article is brought to you for free and open access by UC Hastings Scholarship Repository. It has been accepted for inclusion in Faculty Scholarship by an authorized administrator of UC Hastings Scholarship Repository. For more information, please contact wangangela@uchastings.edu. 


\title{
COVID-19 Antibody Testing as a Precondition for Employment: Ethical and Legal Considerations
}

\author{
Sara Gerke, Gali Katznelson, Dorit Reiss, and Carmel Shachar
}

Keywords: Antibody Testing, COVID-19, Employment, Ethics, Law, FDA, ADA

\begin{abstract}
Employers and governments are interested in the use of serological (antibody) testing to allow people to return to work before there is a vaccine for SARS-CoV-2. We articulate the preconditions needed for the implementation of antibody testing, including the role of the U.S. Food \& Drug Administration.
\end{abstract}

$\mathrm{U}$ ntil there is a vaccine for SARS-CoV-2, we will have to negotiate between the interests of pandemic control through social distancing and the need for people to return to work and travel. Serological (antibody) testing may help bridge that gap by allowing us to identify who is no longer at risk for contracting and transmitting SARS-CoV-2 and letting them resume normal activities, including employment.

Several governments, including the United States, Germany, and the United Kingdom, have suggested that the presence of IgM and/or IgG antibodies to
SARS-CoV-2 may be used to issue "immunity passports" or "certificates." The U.S. Food and Drug Administration (FDA) has already allowed numerous companies to sell antibody tests, and some workplaces have used them, including a law firm in Arizona and firefighters in Illinois. ${ }^{2}$ At the time of writing, the World Health Organization's stance is that there is not sufficient evidence on antibody-mediated immunity to ensure the accuracy of immunity passports. ${ }^{3}$ There may come a time, however, when we know more about COVID-19 immunity and have developed a test that is reliable and accurate enough to warrant further consideration and implementation for broad antibody testing. Mass antibody testing, coupled with PCR testing for SARS-CoV-2, could play a crucial role in restoring our freedom of movement. ${ }^{4}$

In this article, we explore the ethical and legal concerns of tying antibody testing to access to employment. We consider the ethical permissibility of both government required antibody testing programs and private programs initiated by employers in a variety of industries. We also articulate considerations that must be addressed in order for this testing program to be ethically implemented, such as privacy and equity. Lastly, we consider whether federal or state govern-

Sara Gerke, Dipl.-Jur. Univ., M.A., is the research fellow, medicine, artificial intelligence, and law at the Petrie-Flom Center for Health Law Policy, Biotechnology, and Bioethics, Harvard University, Cambridge, MA, USA. Ms. Gerke holds adegree in law (Dipl.-Jur. Univ.) from the University of Augsburg, Germany, and a Master's degree in Medical Ethics and Law from King's College London. Gali Katznelson, M.B.E., is a medical student at the Schulich School of Medicine Eं Dentistry, Western University, London, Ontario, Canada. She holds a Masters in Bioethics from Harvard Medical School. Dorit Reiss, Ph.D., L.L.B., is a Professor of Law and the James Edgar Hervey '50 Chair of Litigation at the University of California Hastings College of Law, San Francisco, CA, USA. She holds a degree in Law and Political Science from the Faculty of Law in the Hebrew University of Jerusalem and a Ph.D. from the Jurisprudence and Social Policy program in UC Berkley. Carmel Shachar, J.D., M.P.H., is the Executive Director of the Petrie-Flom Center for Health Law Policy, Biotechnology, and Bioethics, Harvard University, Cambridge, MA, USA. She holds a J.D. from Harvard Law School and a Masters of Public Health from the T.H. Chan Harvard School of Public Health. 
ments have the authority to mandate testing programs and whether employers can implement testing programs without violating current employment and anti-discrimination laws.

\section{Assumptions}

Our analysis rests on a series of assumptions (see Figure 1). First, we assume that as our understanding of SARS-CoV-2 continues to evolve, there will be reliable evidence to suggest that the presence of antibodies confers meaningful immunity. This could take the form of scientific evidence acceptable to public health expert bodies supporting a link between antibodies and long-lasting. Without that, antibody testing would not provide useful information about who is at risk for COVID-19.

Second, we assume that there is an antibody test for

\section{Regulation of Antibody Tests and Current Concerns}

It is clear that the majority of our assumptions are not yet met. There are serious concerns regarding the accuracy of these tests. ${ }^{7}$ High rates of false positives make reliance on these tests unethical because they might encourage people who test positive but actually do not have immunity to take undue risks. It is the responsibility of the FDA to ensure that antibody tests are ready for widespread clinical use. Recognizing the need for speedy action in the face of a pandemic, the FDA created two pathways to market that would be available only during the public health emergency: 1) "Emergency Use Authorizations" (EUAs), and 2) a May "Policy for Coronavirus Disease-2019 Tests During the Public Health Emergency (Revised)" (May Policy). ${ }^{8}$

\section{Some of the most significant implementation concerns of an antibody testing program as a precondition for employment include concerns about access to the workforce, avoiding incentivizing infections, respecting individual privacy rights, and addressing questions of equity. While we focus on employment specifically, some of these and other ethical concerns have been raised in the context of immunity certification efforts that would relate to broader forms of freedom of movement such as travel, education, or worship.}

COVID-19 on the market that is accurate and reliable with high specificity and sensitivity. We acknowledge the fact that no tests will be $100 \%$ accurate and reliable and that there will always be false positive and negative results. An analogy can be perhaps drawn from vaccines that are also not perfect but are still being (sometimes even mandatorily) used for immunity. ${ }^{5}$ To be considered ethical, antibody testing programs must use only FDA authorized tests meeting a reasonable threshold of accuracy and reliability. A positive antibody test might also need to be coupled with a negative PCR test to ensure that an individual cannot spread the virus. ${ }^{6}$ Lastly, our analysis presupposes pandemic circumstances, including a high risk of infection by leaving self-isolation and a significant risk of death for COVID-19 patients. Should a vaccine or successful treatments for COVID-19 become available, or if rates of infection fall dramatically, antibody testing as a prerequisite for employment may no longer be justified.
The first group of antibody tests for COVID-19 are available through EUAs. The criteria for issuing EUAs are lower than usual (i.e., pre-pandemic) and require, for example, only a "reasonable" belief that the test "may be effective in diagnosing, treating, or preventing" COVID-19. ${ }^{9}$ After determining that there was a public health emergency, the HHS Secretary has issued several EUA Declarations, including one for "in vitro diagnostics for detection and/or diagnosis of the novel coronavirus." ${ }^{10}$ Based on this HHS Secretary's Declaration, the FDA may issue EUAs under Section 564 of the Federal Food, Drug, and Cosmetic Act. To date, the FDA has issued several EUAs for SARSCoV-2 serological tests. ${ }^{11}$

The tests that are available through EUAs have already been rushed through evaluation to market. Even more concerning is that several available antibody tests have not been reviewed by the FDA at all. These are tests that belong to the second group mentioned above - i.e., have not obtained an EUA, but fall within the scope of the FDA's May Policy. To protect the public from a concerning number of antibody tests that are performing poorly or are being promoted 
Figure |

Framework for Considering Testing Requirements

\begin{tabular}{|c|c|c|}
\hline \multicolumn{3}{|l|}{ Assumptions } \\
\hline \multicolumn{3}{|c|}{$\begin{array}{l}\text { - More studies leading to improved scientific understanding of antibody tests (e.g., level of antibodies required for COVID-I9 } \\
\text { immunity, protection length, etc.). } \\
\text { - Reliable and accurate test(s) with high specificity and sensitivity available. } \\
\text { - Positive antibody test with long-lasting immunity (i.e., scientific evidence acceptable to public health expert bodies supporting a } \\
\text { link between antibodies and immunity for a meaningful period of time) potentially coupled with a negative PCR test to ensure } \\
\text { that person cannot spread the virus. } \\
\text { - Pandemic is in effect, including high risk of infection and significant risk of death (i.e., no treatment or vaccine available). }\end{array}$} \\
\hline Industry Characteristics & Employer Initiated Testing & State Required Testing \\
\hline $\begin{array}{l}\text { - Heightened risk to employees } \\
\text { (e.g., meatpacking) } \\
\text { And/or } \\
\text { - Heightened risk to public or } \\
\text { clients (e.g., grocery stores, } \\
\text { healthcare) } \\
\text { Professional duty of care to } \\
\text { patients/consumers }\end{array}$ & $\begin{array}{l}\text { - Ethically permissible } \\
\text { - Few legal barriers }\end{array}$ & $\begin{array}{l}\text { - Ethically permissible } \\
\text { - Federal government may be able to } \\
\text { require for industries engaged in interstate } \\
\text { commerce or transport } \\
\text { - Legal for state governments to require }\end{array}$ \\
\hline $\begin{array}{l}\text { - No heightened risk to employees, } \\
\text { public or clients (e.g., office } \\
\text { workers) } \\
\text { - More limited duty of care to } \\
\text { patients/consumers }\end{array}$ & $\begin{array}{l}\text { - Ethically more controversial, but may be } \\
\text { permissible } \\
\text { - Few legal barriers }\end{array}$ & $\begin{array}{l}\text { - More ethically and legally questionable if } \\
\text { states or federal government can require }\end{array}$ \\
\hline \multicolumn{3}{|c|}{$\begin{array}{l}\text { Concerns that must be addressed for the ethical implementation of either employer-initiated testing or state } \\
\text { required testing }\end{array}$} \\
\hline \multicolumn{3}{|c|}{$\begin{array}{l}\text { - Must be incorporated and harmonized with broader reopening plans to avoid prematurely sending employees back to work, } \\
\text { including educational programs } \\
\text { - Must protect employee privacy to the greatest degree possible } \\
\text { - Must address issues of equity, including access to testing and social supports for retraining when needed } \\
\text { - Outcome, whenever possible, should be reasonable accommodations to allow an employee to work (e.g., remote work, gloves } \\
\text { and masks) rather than denial of employment } \\
\text { - Consider the relationship between antibody testing and vaccine allocation }\end{array}$} \\
\hline
\end{tabular}

inappropriately, the FDA revised its previous March Policy to require commercial manufacturers of antibody tests for COVID-19 to submit an EUA request within 10 business days. ${ }^{12}$ Laboratories that are certified under the Clinical Laboratory Improvement Amendments (CLIA) to perform high-complexity testing can continue to develop and use antibody tests without being required to submit an EUA as long as the test has been validated, the FDA has been notified, and information has been included in the test reports in accordance with the May Policy. ${ }^{13}$

In particular, at the beginning of the COVID19 pandemic, many available COVID-19 tests were flawed based on an assessment by the NIH, and some health care providers had even used antibody tests (wrongly) to diagnose or exclude SARS-CoV-2 infection, which prompted the FDA to revise its Policy. ${ }^{14}$ In light of sound scientific principles, the FDA has repeatedly highlighted that health care providers need to be aware of the fact that the meaning of these tests is limited and that their results cannot be used as the only basis to definitely diagnose COVID-19 or exclude infection with the virus without creating risks to the community and patients. ${ }^{15}$ Looking into the future and broad antibody testing tied to employment, we hope that the FDA will learn from its previous mistakes and ensures that the tests available will meet accuracy and reliability expectations. 


\section{Ethical Issues}

Some of the most significant implementation concerns of an antibody testing program as a precondition for employment include concerns about access to the workforce, avoiding incentivizing infections, respecting individual privacy rights, and addressing questions of equity. While we focus on employment specifically, some of these and other ethical concerns have been raised in the context of immunity certification efforts that would relate to broader forms of freedom of movement such as travel, education, or worship. ${ }^{16}$

\section{Access to the Workforce}

Overall, antibody testing as a precondition for employment is most ethical in situations in which the employee is uniquely vulnerable or likely to transmit the virus to co-workers or clients. Immunization requirements can provide insights related to tying access to work to COVID-19 immunity. We are comfortable with requiring vaccines for certain types of employment. For example, several states require certain vaccines for health care workers, and some of them have lost their jobs for not complying with vaccination requirements. ${ }^{17}$ There is a general consensus that mandatory vaccinations for health care workers is ethically justifiable because these employees owe their patients duties of beneficence and nonmaleficence. ${ }^{18}$ Health care workers are involved with direct patient care, strengthening the argument that hospital and clinic employers have a special interest in ensuring that their employees cannot infect patients/clients. In other words, we want these employees to "do no harm" and find it justifiable to have their employer require influenza vaccinations or proof of immunity against hepatitis B and rubella. In 2015, California passed a bill requiring teachers and volunteers working in day care facilities to be vaccinated against several diseases. ${ }^{19}$ These immunization requirements for specific industries can be distinguished from a broad requirement to demonstrate COVID-19 immunity as a precondition of returning to any work.

Nevertheless, if we find it ethically permissible to compel certain workers to vaccinate, we should similarly find it permissible to impose antibody testing on select industries. Of course, health care workers are in some respects the "easiest" ethical case because of their heightened duties to patients, many of whom will be particularly vulnerable to COVID-19 and because they enter a profession which is already highly regulated in favor of others. Other industries in which there is a heightened risk either to employees, the public, or to clients/patients may also have heightened ethical justifications for antibody testing. For example, since grocery store work requires a sig- nificant level of customer interaction, grocery workers have both increased exposure to SARS-CoV-2 and increased opportunities to transmit the virus. Other industries that may fall into this heightened category are meatpacking, restaurants, and childcare providers. As service providers, these workers owe a greater duty to their customers than citizens sharing a public space might owe one another. Restaurants and daycares, like health facilities, are heavily regulated, as well. These workers are lower paid and more vulnerable than doctors, but they will not necessarily be more vulnerable than service workers in healthcare facilities, and further, their very vulnerability may make it more important to provide a work environment where the risks of COVID-19 are reduced. Because of the compelling interest to keep these workplaces free of COVID-19 outbreaks, it is ethically justified for either states or private employers to require antibody testing for those industries.

What about employers in industries that do not have heightened justifications for requiring antibody testing? It is reasonable for employers to want to avoid COVID-19 outbreaks in their businesses. While financial considerations should not outweigh ethical concerns, ensuring financial sustainability is important, especially considering the economic challenges resulting from expansive stay-at-home orders. It also benefits employees to have employers who are financially stable. Therefore, employees outside of the heightened risk category should be allowed to require antibody testing if they desire so long as they ethically implement these programs. Governmental requirements for antibody testing in these industries may be ethical but the case for these requirements is less compelling than in industries with heightened risk factors. Therefore, federal and state policymakers should proceed carefully with any broader testing requirements.

Not every antibody testing scheme under this rubric is ethical, and implementation has to be ethical, too. We next explore some concerns that must be addressed to ensure that these programs respect individual rights and public policy considerations. State and federal governments should work with employers initiating testing programs to ensure the ethical implementation of these programs.

\section{Incentivizing Infection}

A system that ties immunity to the ability to work creates a perverse incentive. If the reward for immunity is the ticket to employment, people who have not been exposed to the virus may attempt to contract it in the hope of developing antibodies. We may see a proliferation of "COVID-19 parties" ${ }^{20}$ like the "chickenpox parties" that some parents facilitated before a 
vaccine was available. In this respect, antibody testing is significantly different from vaccine mandates. If an employee is missing a mandated vaccination (for example, a flu shot for a health care worker) then they can come into compliance with the mandate by obtaining the needed immunization. On the other hand, if an employee cannot demonstrate COVID-19 antibodies, the only active step they could take to change the situation would be to purposefully expose themselves to COVID-19. In the first case, the employee can meet requirements and obtain employment by taking a safe step that promotes public health. In the other case, the only active option available to the employee is unsafe and undermines public health. In the case of health care workers, purposefully seeking out infection would mean that health care workers must miss work as they recover. In an already stretched health care system, creating an incentive for health care workers to be absent from their clinical responsibilties may harm patients.

Rewarding immunity also potentially undermines the public health efforts of mitigating the spread of COVID-19. Conditioning work on immunity - by incentivizing getting infected - may result in a surge in infections that hospitals may not be able to handle. Moreover, this may erode trust in the public health system. People who have followed public health guidance and avoided developing COVID-19 may now feel penalized by the system by not being able to return to work.

Any antibody testing requirements implemented must be accompanied by policy solutions to address the incentives problem as well. This is true even if the antibody testing program would be entirely employer initiated, because we do not want these programs to undermine public health goals. The first choice should always be to make reasonable accommodations rather than bar individuals from work. In some cases, it is ethically justifiable for the employer to require employees to pass the test. The hospitality and childcare industries, in particular, may find it difficult to redeploy workers because of a limited number of remote or non-client facing positions. But to avoid creating a perverse incentive, most employers should avoid restricting employment to only those COVID-19 immune unless it is impossible to mitigate risk. Other solutions include using antibody testing to create contingency plans for if an outbreak occurs in their locality, in which case immune workers can keep coming in and non-immune work from home. Governments should also invest in retraining programs to ensure that no one is entirely barred from employment due to their immunity status. Moreover, antibody testing programs must be incorporated and harmonized into reopening policies. For example, retail stores should not be able to circumvent stay-at-home orders by conducting antibody testing. Lastly, antibody testing programs should always be coupled with comprehensive and thoughtful educational programs and counseling should be offered for those that are reluctant to take such test. ${ }^{21}$

\section{Privacy}

Another challenge of a system that relies on antibody testing to return to work is that it requires individuals to share private medical information with their employers, government agencies, and other stakeholders. Embracing a widespread antibody testing regimen would require us to rethink our privacy expectations, balancing individuals' interests in controlling their health information with public health interests in sharing the same data.

Pre-pandemic, there was an expectation that employers would generally not be privy to their employees' medical information. For example, the Health Insurance Portability and Accountability Act requires that "hybrid entities," an employer who offers a self-insured health plan to its employees, erect a "firewall" between the part of the company that administers the plan and the rest of the company. ${ }^{22}$ The requirement to establish a firewall suggests that we are uncomfortable with employers having broad access to their employees' medical information.

On the other hand, it is widely acknowledged that a certain amount of disclosure is necessary for certain workplaces. For example, pilots and truck drivers are routinely tested for drugs and alcohol use. ${ }^{23}$ Most health care employers ask for immunization histories from their employees. Some states even require health care employers to ensure that their employees have certain vaccinations. ${ }^{24}$ This suggests that our discomfort with employers' demanding medical information can be mitigated by sufficient justification. For example, pilots or truck drivers operating under the influence can cause crashes. Our discomfort with allowing employers to demand health information without sufficient cause suggests that a narrower immunity requirement would be less fraught from a privacy perspective. Further, in the context of the COVID-19 pandemic, our expectations of medical privacy may already be changing. As part of reopening, many businesses conduct temperature checks for employees, so are already registering and keeping medical information. Arguably, a less frequent antibody test may reduce the collection of medical information, compared to daily temperature checks or symptom monitoring.

To respect individual privacy, we should be sure to limit antibody testing results to as few parties as pos- 
sible. Employers would need to keep individual antibody testing information confidential and should not be permitted to disclose it to patients or clients. To avoid violating their employees' privacy, employers would be able to disclose their plans for ensuring a safe environment for their clients (such as noting that all employees must take their temperature before reporting for work) but not to guarantee or disclose specific health status for individual employees. These privacy measures should be developed anyway, to respond to other health monitoring efforts, and can be applied to antibody testing too.

\section{Equity}

This pandemic has already affected people in inequitable ways. Data from 2017-2018 show that while about half of those in management, business, and financial activity positions could work from home, only $8.8 \%$ of those in leisure and hospitality jobs could do so. ${ }^{25}$ It is not surprising that the unemployment rate for the leisure and hospitality sector was about seven times higher than that of the finance sector in April $2020 .{ }^{26}$ Not only are hospitality and leisure workers likely to find themselves unemployed, but with a pre-pandemic average hourly wage of about $\$ 16 /$ hour, they may not have the savings to withstand prolonged unemployment. ${ }^{27}$ In general, low wage workers are three times less likely to have work that can be done remotely and they are also more likely to have less education, to be young, to belong to an ethnic minority group or to be immigrants, than those who can work remotely, ${ }^{28}$ making it very difficult for these people to secure any employment under stay-at-home orders. Hall and Studdert suggest that an immunitybased employment system may actually benefit some individuals with lower socioeconomic status (SES) since these populations may have a higher prevalence of antibodies due to exposure. ${ }^{29}$ Nevertheless, since the vast majority of Americans at all socio-economic levels have not contracted COVID-19, we anticipate that preconditioning a return to work on antibody testing would not benefit the majority of those with lower SES.

In order to address equity concerns, antibody testing must be widely available so that no one seeking employment is prevented from obtaining a test. Depending on the test(s), large-scale testing may require significant resources such as trained personnel, labs, and personal protective equipment. If these tests are not widely accessible, especially for those who may need them the most to return to work, inequities will only widen. An ethical testing program requires that the employer cover the cost of the tests, just as employers are required to cover protective equipment where it is needed. This raises its own problems of access, particularly for small businesses. It will also be important to ensure that those who test negative for the antibody test are not disadvantaged. Federal, state, and business leaders should build programs to directly address the inequitable impact that testing could have on the ability of those with lower SES to return to work.

Another equity concern, which merits its own paper, will be the impact of antibody testing on vaccine allocation. Many employers already offer flu vaccinations to their employees, and it is possible that they will offer similar access to the COVID-19 vaccination when it is developed and approved. Potentially, this will coincide with an improved understanding of COVID-19 antibodies. If antibodies offer some protection, but not as complete protection as the vaccine, should we take into account antibody status when providing access to the COVID-19 vaccine? Would principles of equity argue that we should actually prioritize those who have already suffered through one bout of COVID19 ? If we decide that people with antibodies should be deprioritized for vaccine access, because they have at least partial protection, how should this be harmonized with the ability to work?

\section{Legal and Policy Issues}

Beyond ethical concerns, including those flagged above, antibody requirements for access to work raise significant legal questions. Distinct questions are raised by government required and employer initiated testing. For government required antibody testing, the operative question is whether there is a constitutional barrier to testing. By contrast, testing initiatives imposed by private employers raise a different set of legal concerns. Foremost is whether employers are allowed to require antibody testing as a precondition to work or whether these demands would run afoul of employment and anti-discrimination laws (or collective bargaining agreements - but because those are very agreement specific, we do not delve deeply into them).

\section{Government Mandated Antibody Testing Programs}

The requirement to "pass an antibody test" as a precondition for returning to work may come from federal or state policymakers. The federal government may lack the power to impose a nationally required antibody testing regimen since its powers are limited to constitutionally allocated powers. Under the commerce clause of the United States Constitution, which gives Congress the power to regulate interstate and international commerce, the federal government can require antibody testing where a business is engaged 
in interstate commerce - including transportation of people or goods across state lines (or internationally), and that would cover a sizable portion of the workforce. Trying to require it from purely intrastate businesses, however, could run into trouble, unless there are good grounds to see them as having substantial effect on interstate commerce.

States, on the other hand, have broad police powers that would allow them to implement required antibody testing programs. As mentioned above, some states have required immunization mandates for influenza for health care workers. Those powers have also been used to impose stay-at-home orders in the vast majority of states. Requiring antibody certificates before returning to work is less coercive than shelter-at-home, and when imposed generally, and with appropriate exemptions, may not violate federal non-discrimination acts. The equal protection clause would also not be a barrier: Since not being immune against COVID-19 does not fall into a protected category, the applicable standard of review would be rational basis, and it is rational to treat people immune to COVID-19 different than those who are not - the latter are at higher risk of getting and transmitting the disease, posing a risk to others.

\section{Private, Employer-Based Antibody Testing Programs} Right now, few would consider not having COVID19 immunity as a disability. Tying access to social goods like employment to COVID-19 immunity raises an interesting possibility that not having COVID-19 immunity would become, in some ways, a socially constructed disability. This would be somewhat analogous to the argument that disability should be understood as "mere difference" - i.e., that non-normative health status or biology becomes problematic because of social structures and expectations rather than because of an intrinsically negative quality. ${ }^{30}$ The Americans with Disabilities Act (ADA) defines disability as "(A) a physical or mental impairment that substantially limits one or more major life activities of such individual; (B) a record of such impairment; or (C) [could be] regarded as having such an impairment."31

In Bragdon v. Abbott, the Supreme Court held that asymptomatic people with HIV qualified as disabled for the purposes of the ADA. ${ }^{32}$ The Supreme Court focused on the immediate physiological effects of even an asymptomatic HIV infection, noting that the "assault on the immune system is immediate." ${ }^{33}$ The Court then found that even an asymptomatic HIV infection limited the major life activity of reproduction. ${ }^{34}$ The Court's emphasis on the physiological impact of HIV would suggest that Bragdon is not actually precedent for declaring a lack of COVID-19 immunity to be a disability under the ADA. In fact, the Court even argued that asymptomatic HIV is a "misnomer" because of the clinical impacts that "persist throughout." 35 Obviously, a lack of COVID-19 immunity is the opposite of an "immediate assault on the immune system" because it means that an individual has not been exposed to the virus.

A stronger argument is that not having COVID19 immunity could qualify as a disability under the "regarded as" prong of the ADA. This prong requires an individual to demonstrate that they are perceived as being disabled, regardless of whether they have an actual physical or mental impairment. In Cook v. Rhode Island Department of Mental Health, Retardation, and Hospitals, the First Circuit concluded that a morbidly obese woman was "regarded as" disabled by her employer because of its concerns around limited mobility and heightened risk of heart disease. ${ }^{36}$ The First Circuit interpreted the "regarded as" prong to allow a suit to be "brought against a warehouse operator who refuses to hire all turquoise-eyed applicants solely because he believes that people with such coloring are universally incapable of lifting large crates." ${ }^{37}$ The EEOC, in its explanation of the "regarded as" prong, cited to "Congress's understanding that 'unfounded concerns, mistaken beliefs, fears, myths, or prejudice about disabilities are often just as disabling as actual impairments,' and [its] corresponding desire to prohibit discrimination founded on such perceptions." 38

A lack of COVID-19 immunity could potentially fall under the "regarded as" prong if employers refuse to hire people who lack COVID-19 immunity because of the perception that they will get sick and not be able to perform their job duties. This could potentially limit the ability of employers to require or use antibody testing to determine who may work. However, we should note that this is a potentially problematic claim: Without testing, there would be no perception of lack of immunity, and using the lack of immunity discovered in testing as a disability would not be an argument against testing. It might be an argument against treating people who tested negative differently, but employers could potentially make a claim that the unprotected are a direct threat to others an exception under the ADA. Further, seeing lack of immunity as a disability could limit employers' ability to demand, for example, vaccines - an undesirable policy consequence.

Current guidance from the EEOC allows employers to require a COVID-19 test, before returning to work because in the circumstances, an individual with the virus would be a direct threat to others. ${ }^{39}$ By contrast, in a technical assistance questions and answers 
document, the EEOC concludes that "an antibody test at this time does not meet the ADA's 'job related and consistent with business necessity' standard for medical examinations or inquiries for current employees." 40 This determination was based on the Centers for Disease Control and Prevention's (CDC) Interim Guidelines for COVID-1O Antibody Testing, which concluded that antibody test results "should not be used to make decisions about returning persons to the workplace." ${ }^{\prime 1}$ The CDC's recommendations, in turn, were based upon the limited understanding of nity would be a direct threat to their workplaces, in contrast to the clear, direct threat posed by those with an active COVID-19 infection. But for workplaces that deal with especially vulnerable clients, such as nursing homes or hospitals, it may be possible to make the argument that anyone vulnerable to infection presents a significant risk. Furthermore, workplaces in which it is likely that employees will be exposed to COVID-19, such as grocery strores, could argue that an employee's ability to perform their essential job functions will be impaired by their vulnerability to infection. Therefore,

\section{Preconditioning access to employment on antibody testing programs has significant parallels to existing immunization requirements in select industries. Because we already allow industries with a heightened justification to compel their employees to vaccinate, we believe that antibody testing programs are likewise ethically permissible for these industries. Similarly, we have not identified a major legal impediment to these programs. In industries without a heightened risk, we believe that employer initiated testing programs would be ethically permissible. State requirements for testing in lower-risk industries, which is likely ethically and legally permissible, is less compelling than for higher risk industries. Any antibody testing program, however, must be carefully implemented to address other ethical concerns, such as privacy and equity.}

any potential immunity or other benefit conferred by COVID-19 antibodies. Therefore, it is possible that in the future, when the science regarding antibody testing improves, that the $\mathrm{CDC}$ will change its recommendations and perhaps trigger the EEOC to reevaluate antibody testing, as it permits COVID-19 testing.

The ADA permits employers to require medical examinations of entering employees, provided all entering employees in the same job category are required to undergo the medical examination. Therefore, once antibody testing provides more useful and actionable information and the CDC changes its Interim Guidelines, employers would likely be able to require antibody testing of all incoming employees. It is less clear if employers could rescind offers of employment based on the result of these tests. In terms of testing current employees for antibodies, the key inquiry will be whether these individuals either 1) post a direct threat to the workplace or they would be unable to perform their essential job functions. Admittedly, it is more of a stretch to argue that people without COVID-19 immu- it is likely that, once we better understand what, if any, immunity is conferred by COVID-19 antibodies, at least some employers will be able to require antibody testing of current employees as "job-related and consistent with business necessity."

Besides the ADA, we can expect some people to raise religious objections to antibody testing, as we see in the influenza vaccines mandate context. The claim would be that the employee has religious objections to the testing and that under the Civil Rights Act of 1964, employers owe them reasonable accommodations. ${ }^{42}$ The range of plausible religious claims is very limited, and sincerity can be an issue. Claims that are raised against vaccines, such as inserting animal products or other things into the body, will not be applicable. Further, the available accommodations are very limited i.e., working at home (or in isolation), where feasible, which would be more viable for some jobs than others. Mask and glove requirements may be a reasonable accommodation, but those carry costs. Remote work would be available for some workplaces, but not others. 
Employers likely have a good argument that exempting employees from antibody testing requirements is an undue burden (which, under the Civil Rights Act of 1964, means anything more than a de minimis cost). ${ }^{43}$

\section{Conclusions}

Preconditioning access to employment on antibody testing programs has significant parallels to existing immunization requirements in select industries. Because we already allow industries with a heightened justification to compel their employees to vaccinate, we believe that antibody testing programs are likewise ethically permissible for these industries. Similarly, we have not identified a major legal impediment to these programs. In industries without a heightened risk, we believe that employer initiated testing programs would be ethically permissible. State requirements for testing in lower-risk industries, which is likely ethically and legally permissible, is less compelling than for higher risk industries. Any antibody testing program, however, must be carefully implemented to address other ethical concerns, such as privacy and equity. A summary of our conclusions is shown in Figure 1.

\section{Note}

C.S. and S.G. work was supported by a grant from the Collaborative Research Program for Biomedical Innovation Law, a scientifically independent collaborative research program supported by a Novo Nordisk Foundation grant (NNF17SA0027784).

\section{References}

1. Q. Forgey, "Fauci: Coronavirus Immunity Cards for Americans are 'Being Discussed," Politico, April 10, 2020, available at <https://www.politico.com/news/2020/04/10/ fauci-coronavirus-immunity-cards-for-americans-are-beingdiscussed-178784> (last visited April 14, 2021); J. Bartlett, "Chile's 'Immunity Passport' Will Allow Recovered Coronavirus Patients to Break Free from Lockdown, Get Back to Work," Washington Post, April 20, 2020, available at <https://www. washingtonpost.com/world/the_americas/chile-coronavirusimmunity-passport-antibody-testing-card/2020/04/20/8dae f326-826d-11ea-81a3-9690c9881111 story.html> (last visited April 14, 2021); D. Roland and D. Gauthier-Villars, "Coronavirus 'Immunity Passport' Stumbles in U.K," Wall Street Journal, April 12, 2020, available at <https://www.wsj. com/articles/coronavirus-immunity-passport-stumbles-in-uk-11586705619> (last visited April 14, 2021).

2. S. Eder, M. Twohey, and A. Mandavilli, "Antibody Test, Seen as Key to Reopening Country, Does Not Yet Deliver," Nerw York Times, April 19, 2020, available at <https://www.nytimes. com/2020/04/19/us/coronavirus-antibody-tests.html> (last visited April 14, 2021)

3. "Immunity passports' in the Context of COVID-19," World Health Organization, April 24, 2020, available at <https:// www.who.int/news-room/commentaries/detail/immunitypassports-in-the-context-of-covid-19> (last visited April 14, 2021).

4. D. M. Studdert and M.A. Hall, "Disease Control, Civil Liberties, and Mass Testing - Calibrating Restrictions During the COVID-19 Pandemic," Nere England Journal of Medicine 383, no. 2 (2020): 102-104, doi: 10.1056/NEJMp2007637.

5. T.L. Wang, L. Jing, and J.A. Bocchini, "Mandatory Influenza Vaccination for All Healthcare Personnel: A Review on Justi- fication, Implementation and Effectiveness," Current Opinion in Pediatrics 29, no. 5 (2017): 606-615.

6. J. Abbasi, "The Promise and Peril of Antibody Testing for COVID-19," JAMA323, no. 19 (2020): 1881-1883, doi:10.1001/ jama.2020.6170.

7. C. Aschwanden, "Antibody Tests Were Hailed as Way to End Lockdowns. Instead, They Cause Confusion," Kaiser Health Neres, May 28, 2020, available at <https://khn.org/news/antibody-tests-were-hailed-as-way-to-end-lockdowns-insteadthey-cause-confusion/> (last visited May 4, 2021).

8. "Policy for Coronavirus Disease-2019 Tests During the Public Health Emergency (revised)," U.S. Food and Drug Administration, May 11, 2020, available at <https://www.fda.gov/ media/135659/download > (last visited April 15, 2021).

9. Federal Food, Drug, and Cosmetic Act, \$ 564(c).

10. "Determination of Public Health Emergency," United States Department of Health and Human Services. February 4, 2020, available at <https://www.govinfo.gov/content/ pkg/FR-2020-02-07/pdf/2020-02496.pdf> (last visited May 13, 2021).

11. "EUA Authorized Serology Test Performance," U.S. Food and Drug Administration, available at <https://www.fda.gov/ medical-devices/coronavirus-disease-2019-covid-19-emergency-use-authorizations-medical-devices/eua-authorizedserology-test-performance> (last visited May 13, 2021).

12. See U.S. Food and Drug Administration, supra note 8 .

13. See U.S. Food and Drug Administration, supra note 8.

14. See U.S. Food and Drug Administration, supra note 8 .

15. "Important Information on the Use of Serological (Antibody) Tests for COVID-19: Letter to Health Care Providers," U.S Food and Drug Administration, last modified April 17, 2020, available at <https://www.fda.gov/medical-devices/lettershealth-care-providers/important-information-use-serologicalantibody-tests-covid-19-letter-health-care-providers?> (last visited April 15, 2021); See also U.S. Food and Drug Administration, supra note 11 .

16. H.T. Greely, "COVID-19 Immunity Certificates: Science, Ethics, Policy, and Law," Journal of Law and the Biosciences 7, no. 1 (2020), available at <https://doi.org/10.1093/jlb/ lsaa035> (last visited April 15, 2021); M.A. Hall and D. M. Studdert, "Privileges and Immunity Certification During the COVID-19 Pandemic," JAMA 323, no. 22 (2020): 2243-2244, doi:10.1001/jama.2020.7712; O.S. Kates, "Show Me Your Passport: Ethical Concerns About Coivd-19 Antibody Testing as Key to Reopening Public Life," Bioethics Forum Essay, May 5, 2020, available at <https://www.thehastingscenter.org/ show-me-your-passport-ethical-concerns-about-covid-19-antibody-testing-as-a-key-to-reopening-public-life/> (last visited May 13, 2021); A.L. Phelan, "COVID-19 Immunity Passports and Vaccination Certificates: Scientific, Equitable, and Legal Challenges," The Lancet 395, no. 10237 (2020): 1595-1598, doi: 10.1016/S0140-6736(20)31034-5; N. Kofler and F. Baylis, "Covid-19 Immunity Testing: A Passport to Inequity, Issues in Science and Technology, April 29, 2020, available at $<$ https:// issues.org/covid-19-immunity-testing-passports/> (last visited April 15, 2021); N. Kofler and F. Baylis, "Ten Reasons Why Immunity Passports are A Bad Idea," Nature 581, no. 7809 (2020): 379-381, doi: 10.1038/d41586-020-01451-0; O.F. Norheim, "Protecting the Population with Immune Individuals," Nature Medicine 26, no. 6 (2020): 823-824, doi: 10.1038/ s41591-020-0896-2; G. Persad and E.J Emanuel, "The Ethics of COVID-19 Immunity-Based Licenses ('Immunity Passports')," JAMA 323, no. 22 (2020): 2241-2242, doi:10.1001/ jama.2020.8102.

17. Valent v. Bd. of Reviere, Dept. of Labor, 91 A.3d 644 (N.J. App. 2014); Robinson v. Children's Hosp. Bos. No. 14-10263-DJC Civ., 2016 WL 1337255.

18. O. Anikeeva, A. Braunack-Mayer, and W. Rogers, "Requiring Influenza Vaccination for Health Care Workers," American Journal of Public Health 99, no. 1 (2009): 24-29; A. Caplan, "Time to Mandate Influenza Vaccination in Health-Care Workers," The Lancet 378, no. 9788 (2011): 310-311. 
19. Day Care Facilities: Immunizations: Exemptions. SB-792 (Ca. 2015-2016)

20. S. Hagar, “COVID Parties' Hurt Everyone," Union Bulletin, May 4, 2020, available at <https://www.union-bulletin.com/ news/health_fitness/coronavirus/covid-parties-hurt-everyone/ article_71f95001-a936-5098-8973-65d20b212c31.html> (last visited April 15, 2021)

21. See Caplan, supra note 18.

22. 45 CFR § 164.105 (2011).

23. "Employees," U.S. Department of Transportation, last modified April 15, 2020, available at <https://www.transportation.gov/ odapc/employee\#drugalcohol> (last visited April 15, 2021).

24. "State Immunization Laws for Healthcare Workers and Patients," Centers for Disease Control and Prevention, last updated November 19, 2014, available at <https://www2.cdc. gov/vaccines/statevaccsApp/> (last visited May 13, 2021).

25. "Job Flexibilities and Work Schedules - 2017-2018 Data from the American Time Use Survey," U.S. Bureau of Labor Statistics, last modified September 24, 2019, <https://www.bls.gov/ news.release/pdf/flex2.pdf> (last visited April 15, 2021).

26. "Leisure and Hospitality," U.S. Bureau of Labor Statistics, May 2020, available at <https://www.bls.gov/iag/tgs/iag70. htm\#workforce> (last visited April 15, 2021); "Financial Activities," U.S. Bureau Labor Statistics, May 2020, available at <https://www.bls.gov/iag/tgs/iag50.htm> (last visited April 15, 2021).

27. See "Leisure and Hospitality, supra note 26.

28. V. Yasenov, "Who Can Work from Home?" IZA Discussion Paper No. 13197 (2020), available at <https://ssrn.com/ abstract $=3590895>$ (last visited April 15, 2021).

29. See Hall and Studdert, supra note 16.

30. I.G. Cohen, C. Shachar, A. Silvers, M.A. Stein, eds. Disability, Health, Lare, and Bioethics (New York NY: Cambridge University Press, 2020).

31. ADA, Section 12102(1)(A).
32. Bragdon v. Abbott. 524 U.S. 624 (1998).

33. Id.

34. Id. at 638 .

35. Id. at 635

36. Cook v. Rhode Island Department of Mental Health, Retardation, and Hospitals, 10 F.3d 17, 23 1st Cir. 1993.

37. $I d$. at 25 .

38. 29 C.F.R. pt. 1630, app. A $\$ 1630.2$ (1)(2012) (citing 154 Cong. Rec. 144, S8346 (2008), H.R. Rep. No. 110-730 at 17 (2008)).

39. "Pandemic Preparedness in the Workplace and the Americans with Disabilities Act," Equal Employment Opportunity Commission, last modified March 21, 2020, available at <https:// www.eeoc.gov/laws/guidance/pandemic-preparedness-workplace-and-americans-disabilities-act> (last visited May 13, 2021).

40. "What You Should Know About COVID-19 and the ADA, the Rehabiliation Act, and Other EEO Law: Technical Assistance Questions and Answers," Equal Employment Opportunity Commission, last modified September 8, 2020, available at $<$ https://www.eeoc.gov/wysk/what-you-should-know-aboutcovid-19-and-ada-rehabilitation-act-and-other-eeo-laws> (last visited April 15, 2021).

41. "Interim Guidelines for COVID-19 Antibody Testing," Centers for Disease Control and Prevention, last modified August 1, 2020, available at <https://www.cdc.gov/coronavirus/2019ncov/lab/resources/antibody-tests-guidelines.html> (last visited April 15, 2021).

42. D.J. Opel, J.A. Sonne, and M.M. Mello, "Vaccination Without Litigation - Addressing Religious Objections to Hospital Influenza-Vaccination Mandates," New England Journal of Medicine 378, no. 9 (2018): 785-788.

43. Trans World Airlines, Inc. v. Hardison, 432 U.S. 63 (1977). 